\title{
SCIENTIFIC PUBLICATIONS OF BRAZILIAN
} MASTOLOGISTS REGARDING ONCOPLASTIC AND RECONSTRUCTIVE BREAST SURGERY: A BIBLIOMETRIC STUDY

\author{
Publicações científicas de mastologistas brasileiros sobre cirurgia \\ oncoplástica e reconstrutiva da mama: estudo bibliométrico
}

Douglas de Miranda Pires¹, Ana Carolina Guglielmelli de Mendonça1', Carolina Nazareth Valadares', Gessandro Elpidio Fernandes Barbosa ${ }^{2 *}$, Victor Bruno da Silva ${ }^{3}$, Ana Maria dos Santos Nunes ${ }^{3}$

\section{ABSTRACT}

Databases available on the Internet are important sources that enable the promotion of knowledge in the health field. Objective: To identify the scientific production of Brazilian mastologists on the subject of oncoplastic and reconstructive breast surgery published between January of 2000 and March of 2016, in the LILACS, MedLine, SciELO, PubMed and Cochrane Library databases. Methods: The identified publications were analyzed from a bibliometric perspective, and some elements such as type of publication, applied methodology, year of publication, number of job citations, Qualis ranking of the journal, number and professional profile of the authors, in addition to the publication development institution were separated and categorized. Results: A total of 631 published papers were analyzed in these databases. 76 publications were included in the final evaluation of bibliometric parameters. More than half of the evaluated publications were from the PubMed database $(78.94 \%)$ and were original articles (57.89\%). The average number of authors per article was 8.48 . The largest number of publications included came from the year 2012 (14.47\%) followed by $2013(13.15 \%)$ and 2015 (11.84\%).A significant percentage of Qualis rated journals were considered very good (A1, A2 or B1). Conclusion: The results show an evolution and an upward trend regarding the participation of Brazilian mastologist authors in national and international scientific productions related to oncoplastic and reconstructive breast surgery. KEYWORDS: Bibliometrics; reconstructive surgical procedures; mammoplasty.

\section{RESUMO}

Os bancos de dados disponíveis na internet são importantes fontes que viabilizam a promoção do conhecimento em saúde. Objetivo: Identificar a produção científica de mastologistas brasileiros acerca do tema cirurgia oncoplástica e reconstrutiva da mama, publicado entre janeiro de 2000 e março de 2016 nas bases de dados LILACS, MedLine, SciELO, PubMed e Cochrane Library. Métodos: As publicações identificadas foram analisadas a partir de uma perspectiva bibliométrica, sendo discriminados alguns elementos, tais como tipo de publicação, metodologia aplicada, ano de publicação, número de citações do trabalho, classificação Qualis do periódico de veiculação do trabalho, número e perfil profissional dos autores, bem como a instituição de desenvolvimento das publicações. Resultados: Foram analisados 631 trabalhos publicados nos referidos bancos de dados, sendo incluídas para avaliação final dos parâmetros bibliométricos 76 publicações. Mais da metade das publicações avaliadas foram provenientes do banco de dados PubMed (78,94\%) e eram artigos originais (57,89\%). O número médio de autores por artigo foi de

Study carried out at Santa Casa of Belo Horizonte - Belo Horizonte (MG), Brazil.

${ }^{1}$ Mastology Clinic, Santa Casa de Belo Horizonte - Belo Horizonte (MG), Brazil.

Instituto de Ensino e Pesquisa, Santa Casa de Belo Horizonte; Santa Casa de Montes Claros - Montes Claros (MG), Brazil.

3Universidade Estadual de Montes Claros - Montes Claros (MG), Brazil.

*Corresponding author: gessandrofernandes@gmail.com

Conflict of interests: nothing to declare.

Received on: 12/12/2016. Accepted on: 05/30/2017 
8,48. Dois mil e doze foi o ano com maior número de publicações incluídas (14,47\%), seguido por 2013 (13,15\%) e 2015 (11,84\%), e um percentual significativo da estratificação Qualis dos periódicos foi considerado muito bom (A1, A2 ou B1). Conclusão: Os resultados demonstraram uma evolução com tendência ascendente da participação de autores mastologistas brasileiros nas produções científicas nacional e internacional relacionadas à cirurgia oncoplástica e reconstrutiva da mama.

PALAVRAS-CHAVE: Bibliometria; procedimentos cirúrgicos reconstrutivos; mamoplastia.

\section{INTRODUCTION}

Breast cancer is a highly prevalent neoplasia and occurs increasingly among women worldwide. The diagnostic and therapeutic advances in breast cancer treatment are constant and the number of women who outlive treatment has expressively grown. In this context, in addition to the issues strictly related to survival and oncologic results, the preservation of femininity associated with the breasts after the cancer treatment, has gained importance in the last years, with regard to aesthetic aspects, quality of life and patient satisfaction ${ }^{1,2}$.

In the last decades, the surgical techniques used for the therapeutic management of breast cancer, have notably evolved, giving preference to procedures which promote both the complete resection of the tumor and the preservation of mammary tissue, which maintains the same oncological safety as other more invasive procedures ${ }^{3,4}$.

In this context, breast-conserving surgery (BCS) stands out, especially after it was reinforced as a safe and effective oncological procedure ${ }^{5}$. It was affirmed by means of a randomized study that BCS associated with radiotherapy is the treatment of choice for women with early stages of breast cancer, and who have similar oncologic results to those of a radical mastectomy. However, about $30 \%$ of traditional BCSs have late aesthetic results, which are considered unsatisfactory by patients. The adoption of preventive measures, along with the association of breast plastic surgery techniques with oncologic surgeries, aims to change this reality. Nowadays, BCSs gain new horizons, with respect to aesthetic principles and quality of life ${ }^{6}$.

Thus emerges oncoplastic breast surgery (OBS), which is defined as the surgical removal of breast tumors followed by reconstructive breast plastic surgery techniques. OBS is based on three pillars:

1. ideal oncological surgery;

2. homolateral reconstruction; and

3. immediate contralateral remodeling.

This new modality allows the patient to incorporate concepts such as integrality and preservation of sexuality into their treatment, as well as the preservation of their body image. Consequently, they will have a less traumatic process of rehabilitation in addition to physical, psychological and social benefits ${ }^{6-10}$.

The OBS allows for many advantages over standard conserving surgeries. It is possible, for example, to extend the lumpectomy with the preservation of breast tissue, resulting in better aesthetic effects. Also, there is the possibility of performing, in a single session, oncoplastic reduction of the breasts and macromastia in women with breast cancer, which promotes greater patient satisfaction and reduced costs. OBSs allow for a greater range of free margins, reducing the need for surgical enlargements. In addition, no statistically significant increase in complications was observed in relation to standard conserving surgeries, indicating that these procedures should be offered to all patients undergoing surgery for oncological breast treatment ${ }^{11,12}$.

Since the advent of OBSs, an increase of texts on the results of these techniques was observed. Many discuss the methods for breast remodeling, including simple techniques, with little mobilizations of the breast, in addition to procedures with large breast volume resection. In this regard, the Brazilian Society of Mastology (Sociedade Brasileira de Mastologia - SBM) released, in 2015, a practical guidebook of recommendations on oncoplastic and breast reconstructive surgeries, in order to clarify several issues, which remained controversial with respect to the indication of each specific technique ${ }^{13}$.

The participation of mastologists in OBSs has been increasing, with improvements in the frequency of professionals who use this technique in their daily routine, as well as through their production of knowledge on the theme, including the development of new surgical techniques ${ }^{14,15}$.

Carrying out a bibliometric study about the scientific production of Brazilian mastologists on oncoplastic breast surgery is important, considering that this methodological strategy allows for the verification of scientific production through a quantitative analysis of the publications. It measures the level of scientific production on a given subject and contributes to the management of scientific knowledge ${ }^{16}$.

Bibliometric studies allow, for instance, to evaluate the places where the studies are disseminated, the temporal evolution of the scientific production, the number of productions per institution and author, the rates of growth and progress in various scientific fields, as well as the impact of these publications on the scientific community ${ }^{17}$.

The objective of this study was to evaluate, from a bibliometric perspective, the scientific production of Brazilian mastologists regarding oncoplastic and reconstructive 
breast surgery, investigating both quantitatively and qualitatively the contribution of Brazilian experience to the world's scientific community.

\section{METHODS}

A systematic search was conducted in the literature for works dealing with the theme of "oncoplastic breast surgery" in the LILACS, MedLine, SciELO, PubMed and Cochrane Library databases. These databases provide scientific works online for the development of bibliographic research. The following main keywords were used in order to create a databank: oncoplastic breast surgery, breast reconstruction, cirurgia oncoplástica $d a$ mama and reconstrução mamária.

The search in LILACS and MedLine was conducted using the following search strategy: the descriptor in the subject field was the term "cirurgia" associated by the connector and to "mama" or "breast" in the words field and, also, the connector and to "oncoplastic" or "oncoplástica" or "oncoplásticas" or "oncoplastics" or "oncoplastie" or "oncoplastique" or "oncoplastische" or "oncoplasty" or "reconstrução" or "reconstrucion" or "reconstruction" or "reconstructive", also in the words field. The search in PubMed was performed according to the following method: (("breast reconstruction”) and "oncoplastic breast surgery”) and (“2000”[Date-Publication]: "3000”[DatePublication]). Concomitant to the search in these databases, the strategy used in the Cochrane Library was: ("oncoplastic breast surgery") or ("cirurgia oncoplástica da mama") or ("reconstrução mamária") or ("breast reconstruction"), delimitating the year with works published from the year 2000 on. In order to avoid occasional losses induced by the use of predetermined descriptors, an empirical search was carried out with 10 authors known to write on oncoplastic surgery in Brazil. This search was based on their historical trajectory regarding scientific events, publications and participation in oncoplastic surgery committees of the SBM.

The inclusion criteria of the studies were: studies published between 2000 and 2016 dealing with the theme of oncoplastic or breast reconstructive surgeries whose authors are Brazilian doctors with the title of Mastologist. All articles published previous to 2000, by foreign authors and/or authors who had no connections to Brazilian institutions, as well as studies whose authors are companies/institutions, were excluded from the present study.

After the initial analysis and quantification of the articles was performed, a file was created in order to catalog them and carry out the bibliometric study of the scientific production. The following data were inventoried:

- database in which the publication was found;

title of the work;

- type of publication;
- subject matter;

- methodology used;

- year of publication;

- qualis classification of the journal in which it was published;

- number of citations of the work informed by the database itself;

- total number of author in the works;

- professional profile of the authors included; and

- institution in which the work was developed.

The evaluation of this study by the Research Ethics Committee was not necessary.

\section{RESULTS}

After the bibliographic search with the proposed methodology, 631 publications were found, 18 of them in LILACS, 267 in Cochrane Library, 30 in MedLine, 169 in PubMed and 147 in SciELO. A total of 555 works were excluded for not meeting the previously established inclusion criteria or for being found more than once among the databases. Only one of the occurrences was considered for the overall count. As such, the sample of this study consisted of 76 articles, and no publications from Medline or Cochrane Library were included (Table 1). Despite the fact that this database provided the largest number of studies for analysis, the vast majority of papers - 246 publications, or $92.13 \%$ - were not of Brazilian authorship, and those that were (11 publications), were not written by mastologists.

Of the 76 publications studied, most of them were original articles (44 articles/57.89\%). Table 1 presents the relation of the remaining types of studies. The most common methodological approaches used in the articles were retrospective (22 articles/28.94\%), prospective (10 articles/13.15\%) and cross-sectional (10 articles/13.15\%).

All works addressing oncoplastic breast surgery and/or direct or indirect breast reconstruction were considered, focusing on surgical techniques, surgical post-treatment complications, quality of life and oncoplastic postoperative aesthetic evaluation, all of which are depicted in Graphic 1. The majority of the works showed the main subject performing breast reconstruction after mastectomy through many techniques, such as myocutaneos or muscular flaps and the use of expanders and prostheses. Due to the fact that the reconstruction of fat tissue (lipofilling) has great prominence among breast reconstruction techniques, a separate category was created for the subject.

Only the citations of works informed by the databases were included, and as such this number was not found in 28 (36.84\%) publications. The maximum number of citations of works included was 20, found in 2 (2.63\%) articles (Table 1). As for the Qualis classification of the journals, the interdisciplinary evaluation was 
considered, and when it was not available, the greatest categorization in Medicine was considered (Graphic 2).

Regarding the year of publication, it was observed that in the years 2007, 2012, 2013 and 2015 there were a greater number

Table 1. General characteristics of the included articles.

\begin{tabular}{|c|c|c|}
\hline $\begin{array}{l}\text { Number of } \\
\text { citations } \\
\text { (quantity/ } \\
\text { percentage) }\end{array}$ & $\begin{array}{l}\text { Type of } \\
\text { publication } \\
\text { (quantity/ } \\
\text { percentage) }\end{array}$ & $\begin{array}{c}\text { Articles found in the } \\
\text { databases (quantity/ } \\
\text { percentage) }\end{array}$ \\
\hline $\begin{array}{l}1 \text { citation } \\
(15 / 19.73)\end{array}$ & $\begin{array}{c}\text { Original article } \\
(44 / 57.89)\end{array}$ & $\begin{array}{c}\text { Cochrane } \\
\text { Library }(0 / 0)\end{array}$ \\
\hline $\begin{array}{l}2 \text { citations } \\
(9 / 11.84)\end{array}$ & $\begin{array}{c}\text { Updated article } \\
(5 / 6.57)\end{array}$ & $\begin{array}{l}\text { LILACS } \\
(1 / 1.31)\end{array}$ \\
\hline $\begin{array}{l}3 \text { citations } \\
(8 / 10.52)\end{array}$ & $\begin{array}{c}\text { Opinion article } \\
(3 / 3.94)\end{array}$ & $\begin{array}{c}\text { SciELO } \\
(15 / 19.76)\end{array}$ \\
\hline $\begin{array}{l}4 \text { citations } \\
(2 / 2.63)\end{array}$ & $\begin{array}{c}\text { Response article } \\
(1 / 1.31)\end{array}$ & $\begin{array}{l}\text { MedLine } \\
(0 / 0)\end{array}$ \\
\hline $\begin{array}{l}5 \text { citations } \\
(3 / 3.94)\end{array}$ & $\begin{array}{c}\text { Review article } \\
(8 / 10.52)\end{array}$ & $\begin{array}{l}\text { PubMed } \\
\text { (60/78.94) }\end{array}$ \\
\hline $\begin{array}{l}6 \text { citations } \\
(2 / 2.63)\end{array}$ & $\begin{array}{l}\text { Letter to the } \\
\text { editor }(5 / 6.57)\end{array}$ & \\
\hline $\begin{array}{l}7 \text { citations } \\
(2 / 2.63)\end{array}$ & $\begin{array}{c}\text { Editorial } \\
(1 / 1.31)\end{array}$ & \\
\hline $\begin{array}{l}8 \text { citations } \\
(1 / 1.31)\end{array}$ & $\begin{array}{c}\text { Case report } \\
(5 / 6.57)\end{array}$ & \\
\hline $\begin{array}{l}11 \text { citations } \\
(1 / 1.31)\end{array}$ & $\begin{array}{c}\text { Clinical trial } \\
(2 / 2.63)\end{array}$ & \\
\hline $\begin{array}{l}12 \text { citations } \\
(1 / 1.31)\end{array}$ & $\begin{array}{c}\text { Audiovisual } \\
(1 / 1.31)\end{array}$ & \\
\hline $\begin{array}{l}13 \text { citations } \\
(1 / 1.31)\end{array}$ & $\begin{array}{c}\text { Not informed } \\
(1 / 1.31)\end{array}$ & \\
\hline \multicolumn{3}{|l|}{$\begin{array}{l}17 \text { citations } \\
(1 / 1.31)\end{array}$} \\
\hline \multicolumn{3}{|l|}{$\begin{array}{l}20 \text { citations } \\
(02 / 2.63)\end{array}$} \\
\hline $\begin{array}{l}\text { Not found } \\
(28 / 36.84)\end{array}$ & & \\
\hline
\end{tabular}

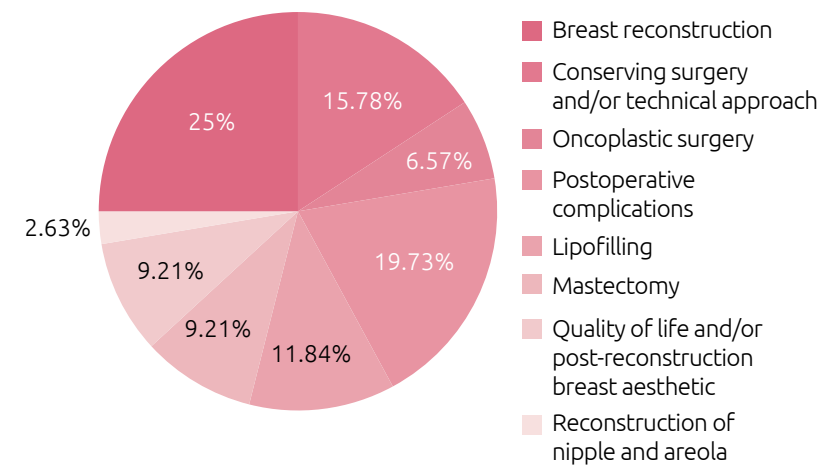

Graphic 1. Subjects approached by the publications included. of productions, with 8 (10.52\%), 11 (14.47\%), 10 (13.15\%) and 9 $(11.84 \%)$ papers published, respectively. Table 2 describes the amount of publications per year in relation to the database and the overall count.

The maximum number of authors in a single study was 17 (1.31\%), the minimum was only $1(1.31 \%)$. The mean number of authors per article was 8.48. A total of 59 different authors were found. Among them, 7 (11.86\%) had a PhD, 22 (37.28\%) were doctors, $12(20.33 \%)$ held a master's degree and 18 (30.50\%) were just specialists. Among the authors found, the

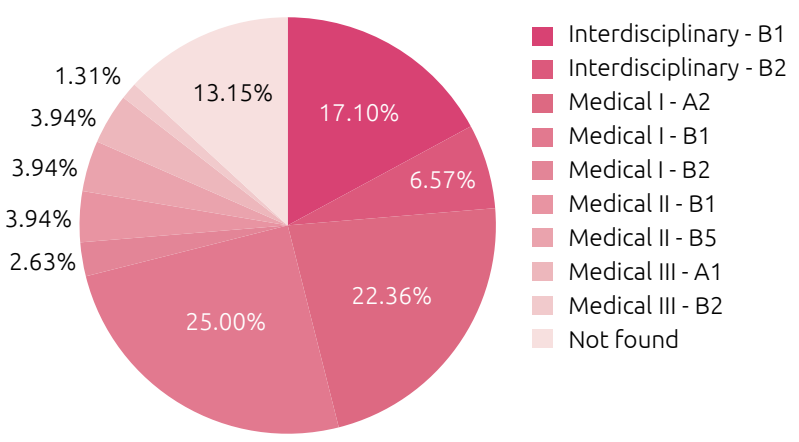

Graphic 2. Qualis classification of the journal.

Table 2. Number of annual publications according to the databases researched.

\begin{tabular}{|c|c|c|c|c|}
\hline Year & PubMed & SciELO & LILACS & $\begin{array}{l}\text { Total number of } \\
\text { articles quantity/ } \\
\text { percentage }\end{array}$ \\
\hline 2000 & - & - & - & - \\
\hline 2001 & - & 1 & - & $1 / 1.31$ \\
\hline 2002 & 1 & - & - & $1 / 1.31$ \\
\hline 2003 & 2 & - & - & $2 / 2.63$ \\
\hline 2004 & - & - & - & - \\
\hline 2005 & 3 & - & - & $3 / 3.94$ \\
\hline 2006 & 2 & 1 & - & $3 / 3.94$ \\
\hline 2007 & 7 & 1 & - & $8 / 10.52$ \\
\hline 2008 & 2 & 1 & - & $3 / 3.94$ \\
\hline 2009 & 2 & 1 & 1 & $4 / 5.26$ \\
\hline 2010 & 2 & 3 & - & $5 / 6.57$ \\
\hline 2011 & 5 & 1 & - & $6 / 7.89$ \\
\hline 2012 & 8 & 3 & - & $11 / 14.47$ \\
\hline 2013 & 8 & 2 & - & $10 / 13.15$ \\
\hline 2014 & 6 & - & - & $6 / 7.89$ \\
\hline 2015 & 8 & 1 & - & $9 / 11.84$ \\
\hline 2016 & 4 & - & - & $4 / 5.26$ \\
\hline TOTAL & 60 & 15 & 1 & $76 / 100.00$ \\
\hline
\end{tabular}


characteristics of five that produced the most are presented in Table 3.

The articles constituting the scope of this study represented 23 institutions, among which include: Brazilian public hospitals $(26.08 \%)$, private hospitals $(8.69 \%)$ and philanthropic hospitals (8.69\%), and Brazilian public (26.08\%) and private $(8.69 \%)$ universities, in addition to Brazilian (8.69\%) and international (13.04\%) institutes. Seven articles represented more than one institution, and 21 of them did not inform the institution where the work was carried out. The institution most often represented by the author was the European Institute of Oncology, in Milan, Italy, especially in scientific productions on prevention, early diagnosis and effective treatment of cancer.

\section{DISCUSSION}

The increasing interest of specialists and the scientific community as a whole in quantitative and qualitative indicators, justifies the need to create mediums for which scientific production may be managed and attested, especially with the growing emergence of research development and funding agencies. Research in this area is a new niche of work for doctors and other health professionals. The creation of databases has an important role in the gathering, selection and evaluation of journals that disseminate scientific production ${ }^{18}$. In this regard, bibliometric analyses are a way to quantify scientific production over time and to evaluate the impact of publications in the scientific community ${ }^{16}$.
Despite the various purposes of a bibliometric study, it has been observed that the development of this kind of study is unusual both in Brazilian and international medical literature, particularly when it comes to themes related to the surgical area, such as breast surgery. As an example of this, in the present study, no publications of bibliometric nature were found.

By analyzing the number of productions published per year on the studied theme, a growing tendency in the amount of publications up until 2012 was observed. This was the year with the highest number of articles. From this year on, there was a stabilizing trend in the number of productions, despite the reduction in 2014. This relation denotes a growing appreciation of the theme among Brazilian mastologists.

It should be noted that almost half of the authors who produced the articles reviewed in this study consist of doctors and $\mathrm{PhD}$ doctors. This shows that Brazilian mastologists that work with scientific production are increasingly interested in the topic. They are always searching for technical and scientific improvement, which positively interferes and impacts the practical aspects of their specialty. Clear proof of this new way of thinking is the number of productions submitted to the last Goiânia Breast Cancer Symposium, held in the country in May of 2016. When compared to the same event held in 2010, a significantly higher number of works were registered (from 30, in 2010, to 165, in 2016) and participants (from 120, in 2010, to 488, in 2016) were observed ${ }^{19}$.

Similar to a bibliometric study on public health and epidemiology carried out between 2000 and 2012 in Germany, most

Table 3. Authors with the highest number of publications on the subject.

\begin{tabular}{|c|c|c|c|}
\hline Author & $\begin{array}{l}\text { Quantity of } \\
\text { publications }\end{array}$ & $\begin{array}{l}\text { Year(s) with } \\
\text { the highest } \\
\text { production }\end{array}$ & Current afiliation \\
\hline Mario Rietjens & 45 & $\begin{array}{l}2015 \text { and } 2012, \\
\text { with } 7 \text { publications } \\
\text { each year }\end{array}$ & $\begin{array}{l}\text { European Institute of Oncology; State University of Milan, Italy; } \\
\text { European Breast Academy; European School of Abdominopelvic Surgery } \\
\text { in Ginecologic Oncology. }\end{array}$ \\
\hline $\begin{array}{l}\text { Angelo Gustavo } \\
\text { Zucca Matthes }\end{array}$ & 9 & $\begin{array}{l}\text { 2016, } 2013 \text { and } \\
\text { 2012, with } 2 \\
\text { publications } \\
\text { each year }\end{array}$ & $\begin{array}{l}\text { Departamento de Mastologia e Reconstrução do Hospital de Câncer de } \\
\text { Barretos, Brazil; Centro de Treinamento em Cirurgia Oncoplástica do } \\
\text { Hospital de Câncer de Barretos, Brazil; Fundação Pio XII, Brazil. }\end{array}$ \\
\hline $\begin{array}{l}\text { Cícero de Andrade } \\
\text { Urban }\end{array}$ & 9 & $\begin{array}{l}2016 \text { and } 2008, \\
\text { with } 2 \text { publications } \\
\text { each year }\end{array}$ & $\begin{array}{l}\text { Sociedade Brasileira de Mastologia; } \\
\text { Hospital Santa Cruz, Rio de Janeiro, Brazil; } \\
\text { Universidade Positivo, Brazil; Conselho Regional de Medicina do Paraná, Brazil; } \\
\text { Hospital de Clínicas da Universidade Federal do Paraná, Brazil; } \\
\text { Santa Casa de Misericórdia de Curitiba, Brazil; } \\
\text { Hospital Nossa Senhora das Graças, Brazil. }\end{array}$ \\
\hline $\begin{array}{l}\text { Fabrício Palermo } \\
\text { Brenelli }\end{array}$ & 8 & $\begin{array}{l}\text { 2011, } 2009 \text { and } \\
\text { 2007, with } 2 \\
\text { publications } \\
\text { each year }\end{array}$ & Universidade Estadual de Campinas, Brazil. \\
\hline Ruffo Freitas- Junior & 6 & $\begin{array}{l}\text { No year had a } \\
\text { greater number } \\
\text { of publications }\end{array}$ & $\begin{array}{l}\text { Hospital Araújo Jorge da Associação de Combate ao Câncer em Goiás, Brazil; } \\
\text { Universidade Federal de Goiás, Brazil; } \\
\text { Sociedade Brasileira de Mastologia. }\end{array}$ \\
\hline
\end{tabular}


works included in the present study were so-called original articles. In addition, this same study showed that Brazil figures among the five countries with the highest scientific production in the world on the themes analyzed by the authors ${ }^{20}$.

When analyzing the data in the present study, it was observed that a significant number of articles were published by high quality journals (Qualis classification - A1, A2 and B1), which means the productions considered here are consistent and demonstrate a good performance in the scientific community, despite the low number of citations informed by the databases. Another aspect to be noted is the fact that most articles are from PubMed, a database offered by the National Library of Medicine of the United States, a database which brings together the leading journals worldwide. This allows us to infer that the studies conducted by Brazilian researchers are important in the medical literature relating to oncoplastic and breast reconstruction surgeries.

No similar studies were found with the same research proposal, thus making this a pioneering study, and proving the importance of the contribution that national experience in oncoplastic and breast reconstruction surgeries has given to the world's scientific community in reporting the production levels of Brazilian mastologist authors. Possible limitations include the fact that many Brazilian authors' resumes found on the Lattes Platform were outdated or incomplete, which may have limited their evaluation. Another limitation regards how the institutions involved were determined, which may have reduced the credibility of the entities that promote the expansion of scientific knowledge.

\section{CONCLUSION}

The works that contain a bibliometric methodological approach constitute an important scientific tool that reveal patterns and trends for research, in addition to sources for obtaining data. The present study points toward a constant evolution in the participation of Brazilian mastologists as authors in the development of studies regarding oncoplastic and breast reconstruction surgeries. As for research persepectives, the temporal evolution of publications demonstrates an increasing interest of mastologists in the theme, indicating a possible growth in the area. Thus, the results presented may serve as a stimulus for other mastologists to learn about the subject and to prepare for this procedure which, when performed, is extremely important for the physical, psychological and sexual well-being of women.

\section{REFERENCES}

1. Brasil. Ministério da Saúde. Instituto Nacional de Câncer José Alencar Gomes da Silva (INCA). Estimativa 2016: Incidência de Câncer no Brasil. Rio de Janeiro: INCA; 2015.

2. Haloua MH, Krekel NMA, Winters HAH, Rietveld DHF, Meijer SB, Frank W, et al. A systematic review of oncoplastic breastconserving surgery: current weaknesses and future prospects. Ann Surg. 2013;257(4):609-20.

3. Fisher B, Anderson S, Bryant J, Margolese RG, Deutsch M, Fisher ER, et al. Twenty-year follow-up of a randomized trial comparing total mastectomy, lumpectomy, and lumpectomy plus irradiation for the treatment of invasive breast cancer. New Eng J Med. 2002;347(16):1233-41.

4. Fisher B, Jeong J-H, Anderson S, Bryant J, Fisher ER, Wolmark $\mathrm{N}$. Twenty-five-year follow-up of a randomized trial comparing radical mastectomy, total mastectomy, and total mastectomy followed by irradiation. New Eng J Med. 2002;347(8):567-575.

5. Veronesi U, Cascinelli N, Mariani L, Greco M, Saccozzi R, Luini A, et al.Twenty-year follow-up of a randomized study comparing breast-conserving surgery with radical mastectomy for early breast cancer. New Eng J Med. 2002;347(16):1227-32.

6. Audretsch WP, Rezai M, Kolotas C, Zamboglou N, Schnabel T, Bojar H. Tumor-Specific Immediate Reconstruction in Breast Cancer Patients. Perspect Plast Surg. 1998;11(1):71-100.
7. Paredes CG, Pessoa SGP, Peixoto DTT, Amorim DN, Araújo JS, Barreto PRA. Impacto da reconstrução mamária na qualidade de vida de pacientes mastectomizadas atendidas no Serviço de Cirurgia Plástica do Hospital Universitário Walter Cantídio. RevBrasCirPlást. 2013;28(1):100-4.

8. Furlan VLA, Sabino Neto M, Abla LEF, Oliveira CJR, LimaAC, Ruiz BFO, et al. Qualidade de vida e autoestima de pacientes mastectomizadas submetidas ou não a reconstrução de mama. RevBrasCirPlást. 2013;28(2):264-9.

9. Sheppard LA, Ely S. Breast Cancer and Sexuality. Breast J. 2008;14(2):176-81.

10. Piper M, Peled AW, Sbitany H. Oncoplastic breast surgery: current strategies. Gland Surgery. 2015;4(2):154-63.

11. Down SK, Jha PK, Burger A, Hussien MI. Oncological Advantages of Oncoplastic Breast-Conserving Surgery in Treatment of Early Breast Cancer. Breast J. 2013;19(1):56-63.

12. Emiroğlu M, Sert İ, İnal A. The Role of Oncoplastic Breast Surgery in Breast Cancer Treatment. Breast J. 2015;11(1):1-9.

13. Urban C, Freitas-Junior R, Zucca-Matthes G, Biazús JV, Brenelli FP, Pires DM, et al. Cirurgia oncoplástica e reconstrutiva da mama: Reunião de Consenso da Sociedade Brasileira de Mastologia. Rev Bras Mastol. 2015;25(4):118-24. 
14. Zucca-Matthes AG, Viera RAC, Michelli RAD, Ribeiro GHFP, Bailão Júnior A, Haikel RL, et al. The development of an Oncoplastic Training Center e OTC. Int J Surg. 2012; 10(5):265-9.

15. Paulinelli RR, Oliveira VM, Bagnoli F, Chade MC, Alves KL, Freitas-Junior R. Oncoplastic mammaplasty with geometric compensation: a technique for breast conservation. J Surg Oncol. 2014;110(8):912-8.

16. Santos RNM. Produção Científica: Por que medir? O que medir? Rev Digital Biblioteconomia Ciên Inform. 2003;1(1)22-38.

17. Reveles AG, Takahashi RT. Educação em saúde ao ostomizado: um estudo bibliométrico. Rev Escola Enferm USP. 2007;41(2):245-50.
18. Mugnaini R. Caminhos para adequação da avaliação da produção científica brasileira: impacto nacional versus internacional [tese]. São Paulo: Escola de Comunicações e Artes, Universidade de São Paulo; 2006.

19. Goiania Breast Cancer Symposium, 2016, Goiânia. I Encontro dos alunos e ex-alunos do programa de educação continuada em oncoplastia e reconstrução mamária da Sociedade Brasileira de Mastologia em Goiânia. Goiânia, 2016.

20. Donner P, Chi P-S, Aman V. Bibliometric study for German National Academy of Sciences Leopoldina in the disciplines Public Health and Epidemiology. Berlim: German National Academy of Sciences Leopoldina; 2014. 